\title{
ON THERE BEING WIDE REFLECTIVE EQUILIBRIA: WHY IT IS IM- PORTANT TO PUT IT IN THE PLURAL
}

\author{
Kai Nielsen ${ }^{*}$
}

Wide reflective equilibrium [WRE] is a distinctive coherentist method of justification or explanation or both, depending on the domain or purpose for which it is deployed. I deploy it principally as a method of justification for accounts of morality and normative political and social theory. But it is also used in many domains from the philosophy of mathematics and science to ethics and aesthetics. When deployed in domains as I deploy it for here, WRE starts with a cluster of societies' specific considered judgments and uncontroversial empirical beliefs and theories and seeks to forge them into a coherent whole along with other considered judgments at all levels of generality. I use it here principally for a justification of political liberalism where it can and should be used for an internal justification, as John Rawls uses it, and as an external justification as Richard Rorty uses it. I use it for both. While these two modes of justification are distinct, they are compatible and importantly so. And for a more complete justification, both are required.

L'équilibre réflectif étendu est une méthode cohérentiste distinctive de justification ou d'explication ou les deux, selon le domaine ou la fin pour laquelle on le déploie. Je le déploie principalement comme méthode de justification de comptes rendus de moralité et de théorie politique et sociale normative. Mais on l'utilise aussi dans plusieurs domaines à partir de la philosophie des mathématiques et de la science jusquà l'éthique et l'esthétique. Lorsquil est déployé dans des domaines comme je le déploie ici, l'équilibre réflectifétendu a comme point de départ un groupe de jugements considérés et de croyances et de théories empiriques non controversées spécifiques des sociétés et cherche à les organiser en un tout cohérent avec d'autres jugements considérés à tous les niveaux de généralité. Je l'utilise ici principalement pour justifier le libéralisme politique où l'on peut et on devrait l'utiliser pour une justification interne, comme le fait John Rawls, et pour une justification externe, comme le fait Richard Rorty. Je l'utilise pour les deux. Quoique ces deux modes de justification soient distincts, ils sont compatibles et ce de façon notable. Et pour une justification plus complète, il faut les deux.

I.

I deploy wide reflective equilibrium [WRE] principally as a method of justifica-

* Departments of Philosophy, University of Calgary/Concordia University. I would like to thank the two anonymous referees for their perceptive and helpful comments. I have tried to respond to them, especially in the Addendum.

(2008) 26 Windsor Y.B. Access Just. 
tion for accounts of morality and normative political and social theory. Here I shall be primarily concerned with how to use it where political morality is being thought about. WRE is a coherentist method of justification. It starts with a society's or a cluster of societies' most firmly held specific particular considered judgments or considered convictions and seeks to forge them into a consistent and coherent whole along with other considered judgments (judgments at all levels of generality) and as well with other relevant beliefs that are generally reasonably, uncontestedly and widely held in the society or cluster of societies with which we are concerned.

It is a coherentist method but with the unique feature - some would say a conflicting feature - that some initial credibility is taken to obtain for those considered judgments themselves that we reflectively endorse and take as our starting points. Their initial credibility will gain in strength for those considered judgments when they get winnowed out as we proceed in equilibrating and continue to be reflectively endorsed at the point where (for a time) we make closure. What we continue reflectively to endorse after such an exercise has considerable weight with us. But these initial considered judgments themselves that we reflectively endorse are not like logical atoms or protocol sentences; for in the very fact of being considered and being reflectively endorsed they cannot stand alone, and their initial credibility obtains not independently of the relations they have with some other beliefs and convictions. Without that they could not even be understood to be something we could consider or to be the result of reflective endorsement. However, without such initial credibility, a purely coherentist method (assuming - what is problematical - that there could be one) would be subject to the standard objection that views may be as coherent as you like but without having any warrant at all, e.g., the belief systems of Christian Scientists or flat earthers.

The thing is to seek to maximize the coherence of our moral beliefs and practices by forging them into reflective equilibrium. It should be a wide (broad) reflective equilibrium and not a narrow (partial) one because beyond collecting together moral judgments, moral practices, medium - level moral rules and moral principles into a coherent whole it also needs to take into account well justified and widely accepted empirical factual beliefs including beliefs about the functions of morality, the functioning of parts of the social structure (including the economy) relevant to social facts, political realities, and relevant scientific developments. WRE, that is, does not work in a moral or social vacuum. How the world goes is not taken to be irrelevant to how morality goes. We seek an equilibrium which takes into account matters such as I have just mentioned, including ascertaining the extent and intractability of the pluralism in our modern liberal societies and whether and to what extent the comprehensive views extant in our societies (or at least some of them) are reasonable. And where some are not, as is most certainly the case, we seek to determine which ones (if any) are such that it would be reasonably possible to (rationally) persuade people holding those unreasonable views to be reasonable thereby abandoning their unreasonable views and, by doing so, moving us along in the direction of a more well-ordered society. We seek to obtain a consistent cluster of moral, political, uncontroversial factual, and uncontroversial theoretical beliefs that would yield the best available 
account of what our social situation is, what the reasonable possibilities are in the society, and what is reasonable and desirable to do. As a bit of ideal theory this is a reasonable thing to say, but whether it has much resonance in the hurly burly of our moral and political lives is very much another matter.

No WRE will be unconditionally final: the 'last word' written in stone. We can be confident that all equilibria will eventually be upset as the world changes including people's perceptions of the world and their reactions to it. However, the method is self-correcting and it is reasonable to hope that if WRE is applied with care, integrity, and intelligence that later equilibria built on earlier ones will tend to be more adequate: that is render more thoroughly and more perspicuously the consistency and coherence of our moral beliefs and practices. But there is no escaping fallibilism (Hume's mitigated scepticism if you will), historicism, or finitism. We never get an equilibrium which says it all, which finally sums things up in a way which is complete and yields a moral view of things that is certain and unconditionally valid. We do not even understand, except perhaps in the vaguest terms, what it would be like to get such a thing.

\section{II.}

Idil Boran and Andrew Lister have launched incisive critiques of my account of WRE. They aim at a place where I may be importantly vulnerable, though I should note in passing that it would not make for trouble as well for the WRE accounts of John Rawls, Norman Daniels or T.M. Scanlon. ${ }^{1}$ It has to do with my rather singular and, as some may regard, my incoherent or at least deeply mistaken, desire to have my Rawls and Richard Rorty too. As a heading to his article, Lister appropriately quotes me as saying, "Moral, social and political philosophy should travel metaphysically and epistemologically light for both Rawlsian and Rortyian reasons which are different but do not conflict." ${ }^{2} \mathrm{He}$ then challenges the claim that they do not conflict and indeed goes on to add that they do not only conflict but conflict in a revealing and important way. ${ }^{3} \mathrm{He}$ made the following remark in his critique of me at a conference in honour of me.

WRE is a nonfoundationalist method of justification in ethics. Two kinds of considerations motivate the development of such a method: a Rortyian denial of the existence of philosophical foundations for knowledge claims and social practices, and a Rawlsian attempt to avoid appeals to controversial religious, metaphysical or philosophical ideas in the justification of social institutions. In the opening quote [the above quote] Nielsen claims that these two motivations do not con-

1 Andrew Lister, "Wide Reflective Equilibrium: Epistomological or Political?" (2006) [unpublished, archived at N.p.]; Idil Boran, "Are some Sailors on Neurath's Ship Moral Philosophers?" in Michel Seymour \& Matthias Fritsch, eds., Reason and Emancipation: Essays in Honor of Kai Nielsen (New York: Prometheus Books, 2007) 261. See also Nielsen's response in Reason and Emancipation.

2 Kai Nielsen, "Philosophy as Wide Reflective Equilibrium" (1994) 43 Iyyun 127.

3 Lister, supra note 1. 
flict. However, the Rortyian reason for not making foundationalist claims is that they are indefensible or incoherent, whereas the Rawlsian reason is that they will inevitably be a matter of deep, reasonable controversy for the design of social institutions. The Rawlsian seeks to avoid the whole debate between foundationalism and anti-foundationalism, and so would not defend WRE on Rortyian grounds. ${ }^{4}$

Boran, as well as Lister, rightly claim that the two types of justificatory appeal for WRE are different and importantly so. Boran is also correct in asserting that if their aim were the same or importantly similar they would be conflicting. She also gives ample evidence that in previous writings I have not kept them properly apart. And she is justified in saying that Rawls would not, and indeed could not, avail himself of the Rortyian justification for appealing to WRE. If he did, Rawls would be violating his own restrictions on justifying political liberalism without making any controversial philosophical claims or moves whatsoever. Rejecting foundationalism and taking an anti-foundationalist or even a non-foundationalist stance is one such controversial claim. Perhaps it is well justified (indeed, I think so) but it is controversial. It is metaphysical as Rawls uses 'metaphysical' in a broad sense to designate any controversial philosophical view. ${ }^{5}$ Rawls, in defending political liberalism and in using WRE to defend it, does not criticize or reject foundationalism or adopt non-foundationalism but just benignly sets aside such issues.

However, WRE is a procedure and it can be used for different purposes. Rawls uses it for one purpose, as described above, and Rorty and I use it for different purposes but purposes that do not conflict with Rawls's. (Indeed, I also use it for Rawls's purposes.) Rawls's deployment of WRE is, I shall argue, safe and home just as he deploys it for his quite legitimate purposes. But his purposes are not the only legitimate purposes for which WRE can be deployed even when only political liberalism is at issue. And some other deployments of WRE do not operate with the same constraints. I shall try to make these dark sayings clear and hopefully persuasive. ${ }^{6}$

It is crucial to recognize, as Burton Dreben has (as well as Norman Daniels

4 Ibid. at 1.

5 John Rawls, "Justice as Fairness: Political not Metaphysical" (1985) 17 Philosophy and Public Affairs 251 [Rawls, "Justice as Fairness"].

6 In speaking of 'varied uses of WRE' I mean that this procedure can be deployed for different ends or purposes. It can be used in science, logic, metaethics, epistemology, aesthetics, and even metaphysics, as well as politics, and moral philosophy. It tries to get in these different domains, and articulated in a coherent way, a coherent account in which their various most firmly held beliefs (and in some cases convictions) are shown to fit together consistently and coherently. Where (if at all) a political system (conservatism, political liberalism, a hierarchical corporatism, socialism, communism, fascism) can make a claim to justification, the judgments that for it are its considered beliefs or (in some cases) considered convictions must be forgeable into a consistent and coherent set or whole. This is a necessary but not a sufficient condition for an adequate justification. The considered judgments that get equilibrated must also be thought to have some initial credibility by the people who accept that belief system. And indeed they must have some initial credibility, at least for them. Many philosophers (as well as others) will want more. But it is, I believe, an illusion to think that they can get more. 
and T.M. Scanlon), how Rawls came to have, particularly from his Dewey lectures on and culminating in Political Liberalism and The Law of Peoples, a very constrained but creatively determinate purpose. ${ }^{7} \mathrm{He}$ saw that the extant defenses of political liberalism (social democracy if you will) had internal conflicts: conflicts that its adherents had not been able either to resolve or plausibly dissolve. ${ }^{8}$ He set out to present a way of understanding political liberalism that would enable us to see it as something free of those conflicts: free most centrally of conflicts between liberty and equality and of any entrenched conflict between the liberties of the ancients and the liberties of the moderns and how there was in political liberalism a conception of tolerance that made sense of political liberals' relations to non-liberal peoples and did not come to ethnocentrically imposing liberal views on them. His aim was, taking it as given that political liberalism was an attractive view to which he and many others were committed, to articulate an account of political liberalism that could plausibly be seen to be a consistent and coherent view that was perspicuously displayable. Rawls sought to articulate a view, taking into account the varied comprehensive doctrines of liberals in such democracies, which yielded an overlapping consensus concerning our political lives together. One very central element of it was to be committed to the toleration of conflicting metaphysical and religious or non-religious comprehensive conceptions of how life is to be lived, no matter how deep their conflicting metaphysical and religious or non-religious beliefs, as long as, in the very minimal sense Rawls had in mind, these various comprehensive views of the good were reasonable. If this obtains for them they will come to agree on a commonly acceptable family of conceptions of a broadly egalitarian conception of political justice. ${ }^{9}$ In achieving such a WRE to utilize for his defence of political liberalism and for a defence of liberal societies (which also must be constitutional democracies) he articulated, at least arguably, a view, given the pervasive and intractable debates about liberal democracies, that was a very considerable achievement indeed. ${ }^{10}$

It is very important to see how minimal this sense of being reasonable is and how keeping it so is essential for gaining agreement concerning and reflective endorsement of the adequacy of his conception of political liberalism. But it is also important to keep firmly in mind a point Rawls makes himself that justification is always for a particular audience at a particular time and not ever for humanity

7 Norman Daniels, “Democratic Equality: Rawls's Complex Egalitarianism” in Samuel Freeman, ed., The Cambridge Companion to Rawls (Cambridge: Cambridge University Press, 2003) 241; Burton Dreben, "On Rawls and Political Liberalism" in Samuel Freeman, ed., The Cambridge Companion to Rawls (Cambridge: Cambridge University Press, 2003) 316; T.M. Scanlon, "Rawls on Justification" in Samuel Freeman, ed., The Cambridge Companion to Rawls (Cambridge: Cambridge University Press, 2003) 139.

8 Rawls remarks in the preface to the French translation of $A$ Theory of Justice that what he calls "justice as fairness" and calls a liberal view would in Europe be called "social democratic, and in some ways as labor." (John Rawls, "Preface for the French Edition of a Theory of Justice" in Samuel Freeman, ed., John Rawls: Collected Papers (Cambridge, MA: Harvard University Press, 1999) 415 at $415-416$.

9 Justice as fairness is one member, perhaps the most prominent member, of a family of liberal (social democratic) conceptions of justice (John Rawls, "The Idea of Public Reason Revisited" in Freeman, supra note 8, 573 at 581 .

10 Dreben, supra note 8. 
at large. ${ }^{11}$ The justification Rawls proffers is for liberals themselves and not for all and sundry. Liberals can come to see that political liberalism is not ad hoc and is not a conflicting or (if there is such a thing) an incommensurable jumble but something that hangs together for them in an attractive way. Leaving out 'in an attractive way,' non-liberals may see that coherence too but since some of their considered judgments are importantly different from Rawls's (or for that matter mine), Rawls's liberal WRE will have little hold on them. They can see its coherence and still shrug their shoulders. Rawls does not try to argue that they are justified in so reacting or that they should not so react or that anything like a justification here is impossible or unimportant. To do that is not what he is trying to do. It is not his kettle of fish. It is not what he set out to accomplish. What he most centrally set out to accomplish, specifically in Political Liberalism, is what I have described in this paragraph.

Rawls's justification of political liberalism is an internal one, making minimal claims on those committed to political liberalism and who accept its orientation and the ethos of its background culture, but who will often have very different comprehensive conceptions of the good. Starting with their considered judgments, concerning which he believes there is a considerable consensus among liberals, Rawls sought to get their views into WRE. He did not seek to show (though he also did not deny or affirm that it could be done) that political liberalism could be justified to someone trying to advocate some form of an aristocratic hierarchical society, a Leninist communist society or a fascist society, or to someone trying to advocate a serf or even a slave society. And he did not claim to have arguments sufficient to turn their minds around if they would be reasonable. Rawls was not concerned to present an argument that would require for everyone, if they would be rational, to turn their heads around - or to re-attune their hearts - and become political liberals. Though he, like most of us in our societies, thought some of these non-liberal views, which were also illiberal, were very implausible and in some instances evil. But Rawls did not think that anyone, anywhere, no matter what his situation and particular socialization and culture, would recognize, or have grounds for accepting, justice as fairness or any of the related family of politically liberal political conceptions of justice. He was not in the business of answering Calvin or Luther or Nietzsche or Karl Schmidt or Lenin or Marx or fundamentalists of any stripe. He did not say that it could not be done or that it could be done or even that it should be done, but rather gave to understand that that was not his task. He sought instead to present political liberalism in a coherent way and to convincingly show how he could make it coherent and plausible even to political liberals aware of the difficulties in extant liberal accounts. To do this he crucially and distinctively deployed WRE. He deployed it in a manner that travelled philosophically light, taking no positions at all that were philosophically controversial. He did not deny there may be a deep, contested truth or soundness in political liberalism, but responded that the person committed to political liberalism need not invoke or even grasp such a truth or soundness (if indeed there is one) to achieve agreement with other political

11 John Rawls, A Theory of Justice, rev. ed. (Cambridge, MA: Belknap Press of Harvard University Press, 1999) at 506-514 [Rawls, Theory of Justice]. 
liberals who hold very different metaphysical and epistemological views. For example, a secularist political liberal could say to a Thomist political liberal, 'Perhaps you are right. There may be natural moral laws rooted in God's reason and they may be the ultimate ground for our shared considered judgments. But I, along with a not inconsiderable number of reasonable others, do not agree with you about that and I, as well as others - reasonable others - even after considerable argument and dialogue, are not very likely to come to agree with you about these philosophical matters. But there is agreement between us - between you and me - about a whole host of considered judgments themselves. So wherever the philosophical quest may take us, for political purposes - for our attaining a common political rationale for our political liberalism - we can, and should, bracket such controversial philosophical questions. We can for political purposes benignly neglect them, even if we, when we are philosophizing, seek to ascertain the truth - if you will, the warranted assertability - concerning what we severally and differently and perhaps irreconcilably, given the burdens of judgment, disagree about concerning what we are to take to be the deep ultimate basis or lack thereof for our allegiance to political liberalism.' To expect agreement about these controversial philosophical matters - in Rawls's terms, metaphysical matters - is utterly unrealistic; but it is not unreasonable or implausible to expect agreement concerning a whole host of commonsense considered convictions and beliefs and about how they fit together.

It is important to recognize, as Rawls stresses himself, and Boran rightly reiterates, that this is not to be confused with a scepticism (say, a Mackie-type error theory) or a Rorty-like anti-foundationalism or Rorty's and my anti-Philosophy philosophy or even (as, is evident, he commits himself to in his Dewey lectures) a Rawlsian meta-ethical Kantian constructivism. ${ }^{12}$ We simply bracket these things when what is at issue is an internal political justification of political liberalism in an attempt to make it plausible to people who are already political liberals but worry about its rationale or even its consistency.

However, 'being bracketed from' is one thing and 'being incompatible with' is

12 'Anti-Philosophy philosophy' will sound wilfully paradoxical without some explanation. It rests on a distinction Rorty draws in his book: Consequences of Pragmatism (Minneapolis: University of Minnesota Press, 1982) at xiv-xix. Rorty writes, "philosophy' like 'truth' and 'goodness' is ambiguous." A little 'p' 'philosophy' can mean simply what Wilfred Sellars calls "an attempt to see how things, in the broadest sense of the term, hang together in the broadest sense of the term." Here talk of 'philosophy' is at least reasonably unproblematical and many people - George Elliot or Thomas Hardy, for example - who are normally not thought of as philosophers are in that sense philosophers, and sometimes much more so than some of the professionals. Philosophy (with a big P) denotes something more special such as the metaphysical and epistemological activity characteristic of Plato and Kant as well as their contemporary heirs, such as Kripke and David Lewis. This Rorty regards as a very dubious activity, indeed up for Wittgensteinian dissolution. But whether that is so or not, it remains important to distinguish philosophy and Philosophy. One might be for the former without being for the latter, and if anti-Philosophy philosophy is on the mark, as both Rorty and I think it is, then one should be for undermining Philosophy and for practicing philosophy. Wittgenstein to my mind - though he certainly would not say anything so crude - is the best example we have of an 'anti-Philosophy philosopher.' See Kai Nielsen, "Anti-Philosophy philosophy" (1994) 64 Diálogos 149 [Nielsen, "Anti-Philosophy"] and Kai Nielsen, Naturalism without Foundations (Amherst, N.Y.: Prometheus Books, 1996) at 200-201, n 1. [Nielsen, Naturalism]. 
another. For his particular purposes - fundamentally political purposes - Rawls cannot appeal to what has been called (I think mistakenly) epistemological/Rortyian reasons or any controversial epistemological reasons or anti-epistemological stance or anything else philosophically controversial. They are not part of the language-game Rawls is playing in defending political liberalism; they are not the practices he utilizes in seeking to place political in his WRE. But a political liberal who wants to answer Karl Schmidt or Aquinas or Mao or Lenin is playing another importantly different language-game, also distinctively politically liberal, but for a different but (or so I claim) non - conflicting purpose. To give an internal political justification of political liberalism - to show how political liberalism plausibly hangs together - is one thing, and to give an external political justification of political liberalism - showing its superiority to hierarchical aristocratic systems or to fascism or Soviet Union style communism in Statist post-capitalism - is another. These tasks are not the same tasks but just different tasks with different ends in view. This is not to show or to say that they stand in conflict or to give any credibility to that claim.

III.

With the above I am inching closer to showing how I can consistently and coherently have my Rawls and Rorty too. They are playing different language - games for different purposes but not, for all of that, conflicting purposes, or at least not necessarily conflicting purposes. I did not say 'incommensurable' purposes but just 'different' purposes. Or to use a different jargon, they, in asking about the justification (perhaps better, 'a justification') of political liberalism, have what John Dewey calls different ends in view. ${ }^{13}$ Rawls wants an internal justification of political liberalism showing how it hangs together, how it is a consistent and coherent view meshing with our considered judgements. . But he neither affirms nor denies that an external justification is possible. Rorty presumably wants the same thing, but he is concerned as well with an external justification of political liberalism. He is concerned with how, if pushed, political liberalism could respond to a Karl Schmidt or a Lenin. His own examples are Nietzsche and Loyola but the issue remains the same. ${ }^{14}$

Rorty gives his contextualist, historicist, finitist, social practice - oriented, if you will, Wittgensteinian answer. ${ }^{15}$ We never can gain, he argues, some standpoint where we can, standing free from any perspective, neutrally assess such matters. It is unintelligible to try to set aside all our social practices and gain a perspectiveless view from nowhere - say, Sidgwick-style from 'the point of view of the universe'- where we can come to see that some regimes of practices are justified and others are not. (However, Rawls could not take such views for they are controversial philosophical views and thus for him metaphysical views.

13 John Dewey, Human Nature and Conduct: An Introduction to Social Psychology (New York: Modern Library, 1922), 223-237.

14 Richard Rorty, Objectivity, Relativism and Truth (Cambridge: Cambridge University Press, 1991) at 175-196 [Rorty, Objectivity].

15 Ibid. 
He seems in his later thought to be in practice very much a historicist, though he would not say this. He could not acknowledge that, for it would be or so it seems inconsistent with his eschewing what he takes to be metaphysical views in arguing for political liberalism. That is a way, as Rorty does and as I do, to characterize his views - I think an accurate way - but Rawls need not do so himself in showing how political liberalism hangs together.) But it would be harder for him in characterizing what justification consists in, namely that it is something that obtains for a certain people at a certain time and place and for people with certain interests. That notwithstanding, political liberalism, fascism, Stalinist 'communism', Calvinism, Loyolaism, the various religious fundamentalisms, are just not for Rawls on the agenda. But holders of such deeply illiberal views will return the compliment. For some the very word 'liberal' is a derogatory term. A liberal can, of course, give a bucketful of reasons for rejecting these illiberal views. They are intolerant, fanatical, show a kind of disrespect for persons, an indifference to liberty, cause extensive misery, have (in some instances) irrational conceptions of what the world is like, etc. etc. But such remarks will not faze the illiberal opposition. These reasons are all, they affirm, question-begging. They (depending on what kind of an illiberal is involved) will say these secularly oriented political liberal responses ignore the utter transcendence of God and the unquestionable unchallengeable authority of His law or the wisdom of the Führer and his call for the racial solidarity rooted in 'racial science' and the purity of his New Order or the historical reality of the proletariat and the clear practical understanding by them that capitalism will break down of its own internal contradictions, something shown to the proletariat (and only to them) in the turmoil of their everyday life and so on and so on. (This latter is something that Georg Lukács argued). ${ }^{16}$

Political liberals will not say or even think, as when pushed very far extreme illiberals will, that 'I have the right to persecute you because I am right and you are wrong. I have the truth and you do not. My beliefs are true and yours, and importantly and dangerously so, are not, and I must do everything I can to see to it that my views prevail.' Moreover, any uncorrupted person, an illiberal could go on to say, can see that or indeed any right thinking person can see that. Such an extreme illiberal (and they are plentiful) will add: 'Given those corrupt views of yours or patently false views of yours, there are no good reasons for being tolerant of you, except perhaps sometimes tactical reasons of expediency when the balance of forces outweigh us.' Many of them will say (and differently for different illiberal views) 'We cannot by any means respect or even tolerate Tutsis, Muslims, Jews, Hindus, Christians, Communists, Fascists or atheists.' Tolerance for illiberals has at best instrumental value only and need not be rooted in respect for persons. They may even be so fanatical, as Nazi ideologues were, to believe that some life is unworthy of life. Here the liberal very well may feel with Wittgenstein that justification has come to an end and that his spade is turned. Our views of life and its worth, he may well feel, are so different from those of that collection of illiberals that nothing further can be said.

16 Georg Lukács, History and Class Consciousness, trans. by Rodney Livingstone (London: Merlin Press, 1971). 
Other political liberals, John Dewey for example or myself, will think that inquiry and justification never come to a dead stop such that, even after a period of cooling off and reflection, nothing more can possibly, relevantly be said. Moreover, if that was so, we could not know that it is so, which is tantamount to saying it never comes to an end. Rorty will say, as I would as well, that whatever 'answer' there is, if any, we can never escape fallibilism, perspectivism, historicism, and finitism. There are no giants or gods or an absolute perspective - some view from nowhere, some point of view of the universe. Whatever is said at a given time may be upset at a later time. There is no unconditional validity, no Archimedean point, and no ahistorical perch. There is, that is, no escaping perspectivism. (But is this not, however well justified, to take what Rawls would regard as a metaphysical view? Do we need to do this to show the coherence of political liberalism?) I think we do. Justification is time-dependent though truth is not. But there is no attaining truth, as distinct as it is from some time dependent as warranted assertability, let alone The Truth, whatever (if anything) that means. We can only gain, with luck and careful reasoning, warranted assertability for a particular time and place. But we can sometimes get that and that is not nothing. And that is something that we can reasonably commit ourselves to.

Justifications of truth-claims arising from our various inquiries may appear to be, and perhaps actually are, more adequately justified than the ones that came before them or some other purported justifications that are contemporaneous with them. But convergence here is neither inevitable nor assured beyond reasonable doubt. The most we can hope for is the best justified belief we can for a time get. But that, to repeat, is always time and place dependent. We can never gain some history transcendent viewpoint where we just have the truth or something that is warrantedly assertable period.

Many, perhaps most, political liberals will take this to heart and draw the consequences in a way people holding illiberal viewpoints generally do not. Many political liberals may come to see that there is no escaping perspectivism and with it a historicism, finitism, and fallibilism - Hume's mitigated scepticism, if you will. Many political liberals may come with that understanding to see - though some may continue to think this is a bit too extreme - that though we can have reasons for what we do or think they can never be more than historicist/fallibilist reasons. This, of course, is a contestable and contested philosophical position that Rawls, given his own methodological commitments, must bracket as he also must bracket asserting the opposite. They are both what he calls metaphysical views.

Such a historicism shows its head in claims concerning how to argue (if political liberals choose to do so) about the relative merits of political liberalism vis -à-vis the range of illiberal or non-liberal views. We cannot escape assuming this or some other contestable philosophical position in arguing with this assortment of illiberals. But Rawls resolutely refuses to take any such argumentative route. But to take such a controversial argumentative route, as Rorty does or I do, in trying to answer the questions concerning how to answer a Karl Schmidt, does not conflict with Rawls's avoidance of metaphysics (for him, remember, any controversial philosophical view). It is just (to repeat) that they are different things - indeed different things that a consistent political liberal may legitimately do - with different rationales for different purposes. Rawls tries to justify 
political liberalism internally by showing how it can be a consistently, perspicuously, and attractively arranged position without departing from the considered convictions that all political liberals could accept. His aim is to show how political liberalism can be rendered consistent and coherent. I seek in addition to defend it in competition with and from challenges from various illiberal views and particularly from the strongest ones that can be mustered.

It is important to recognize that in both Rawls-type arguments and in Rortytype arguments for political liberalism "WRE is employed" and "its core is the same thing." It is the same procedure. It functions with deeply embedded beliefs and considered judgments at all levels (particularly those most characteristic of the background culture of political liberalism). In doing so it attempts to forge a consistent and coherent (perhaps this comes to the same thing) set of beliefs into a coherent and perspicuously displayed whole that will yield both an explanation and a justification of the relevant phenomena. Yet some WREs, while in that respect the same, will be different in having different objectives, sometimes using partially different considered judgments and beliefs as 'raw material.' They will use the same procedures but utilize some different beliefs in their different WREs. This even obtains concerning an attempt to justify political liberalism. Some, as I have said, seek an internal justification and some will seek an external one and some, as I do, (perfectly consistently) will seek both. (Those who seek external justification will presuppose political liberalism's coherence.) The considered judgments to be forged into a coherent whole will, in some significant instances, be different depending on which type of justification is at issue. In a Rawls-type justification of political liberalism all the considered judgments placed in WRE must be philosophically (in his sense metaphysically) neutral and must be acceptable to all those who partake of the ethos of political liberalism. Remember this type of justification is an internal one attempting to show how political liberalism can be shown to form a consistent, coherent and attractive whole. The Rorty-type justification will also collect together all the same type of considered judgments, but will as well have contested-type philosophical claims to be fitted together with the non-contested considered judgments in that WRE. Those contested philosophical principles are those it is necessary to deploy to relevantly respond to various illiberal or non - liberal claims so as not to just beg the question with them. But both have WRE arguments utilizing a common method. It should also be noted that the various illiberal or non-liberal positions could themselves deploy at least some narrow reflective equilibrium in a consistent way. For them, however, the move to WRE is more problematic. Some such illiberal or non-liberal peoples living under conditions of modernity will have a number of what they regard as well-established theoretical empirical beliefs and other empirical claims that they would at best have a hard time consistently accommodating in their WRE. ${ }^{17}$ This will not be true, or at least less likely to be true, of political liberals. But, ignoring such modernist and enlightenment claims, they perhaps could manage coherence as well as a political liberal if such non-liberals restrict themselves to a narrow reflective equilibrium. But with his WRE the political liberal could appeal to some often mundane uncontroversial

17 Nielson, Naturalism, supra note 12 at 79-155. 
beliefs that illiberals and other non-liberals also accept. But there are beliefs in his WRE which are not compatible with other beliefs or considered judgements of such non-liberals while they are compatible with the full range of the political liberal's views. ${ }^{18}$

We should not forget, moreover, that the method of WRE was used by Nelson Goodman in epistemology (or what was so labelled; perhaps 'non - foundationalist epistemology' is not an oxymoron). ${ }^{19}$ If we balk at such an 'epistemology,' regarding it as a non-subject, we can call it 'theory of inquiry' or just plain 'inquiry' instead..$^{20}$ It was also in effect used in the philosophy of science by Quine and I have used it to attempt to show that at least theistic religions could not, under conditions of modernity, be in WRE, for too many theistic religious beliefs conflict with well-established scientific beliefs. ${ }^{21}$ We cannot get for we moderns a WRE here. ${ }^{22}$ But for Jews, Christians, and Muslims living in the Middle Ages, their beliefs could perhaps have been forged into partially different, but not completely different, WREs for each with their distinctive ideas of redemption. Something like this also may even be true for isolated and marginalized groups in our time such as the Amish and Hutterites.

However, the general point is that WRE could, and perhaps should, be used for the full range of belief-systems or forms of life or conceptions of things from philosophy of mathematics to thinking about science, religion, morality, politics, law, to society more generally, to aesthetics. The same core coherentist method - a distinctive procedure - would be applied in all domains. Sometimes what are appealed to are considered judgments, sometimes mathematical truisms, sometimes widely acknowledged empirical data and well-established hypotheses, and, for some peoples in some situations, religious beliefs and doctrines and their associated considered judgments, and sometimes a mix of some of these things. Sometimes WRE seeks only explanation or only justification and sometimes both. But always there is a similar procedure. But to return to Rawls's, Rorty's and my dispute about political liberalism, there is a difference between some of the sorts of reasons that get appealed to, but there is no conflict between them, given they have different ends in view, concerning the justification of political liberalism. Moreover, they all utilize the same core method of WRE. I can consistently have my Rorty and Rawls too.

IV.

In the above I have used 'reasonable,' as does Rawls, Scanlon and Barry, lavishly, perhaps too lavishly. I, like Rawls, do not assume or think 'the reasonable'

18 Ibid.

19 Nelson Goodman, Fact, Fiction and Forecast (Cambridge, MA: Harvard University Press, 1955) at 65-8.

20 Isaac Nevo, "Reflective Equilibrium and the Contemplative Ideal of Knowledge" (1998) 1:2 Philo 22; Richard Rorty, Philosophy and the Mirror of Nature (Princeton, N.J.: Princeton University Press, 1979); Kai Nielsen, After the Demise of Tradition (Boulder, CO: Westview Press, 1991) at 39-90; Kai Nielsen, On Transforming Philosophy (Boulder, Co.: Westview Press, 1995) at 85-192.

21 W.V. Quine \& J.S. Ullian, The Web of Belief (New York: Random House, 1978).

22 Nielsen, Naturalism, supra note 12 at 79-113. 
can be derived from 'the rational' (let alone be identified with it) or that 'the rational' is a more basic concept that we need to make sense of 'the reasonable.' Both concepts are essential in social life or indeed life period. But they have different uses.

I want now to explore a bit of Rawls's use of 'the reasonable' for I think it is important not only for its own sake but for understanding what is at issue between Boran and myself. In doing so I shall bring out an important but neglected aspect of Rawls's thought that helps, if thought through, to further my case that we can and should deploy a case for political liberalism along Rortyian lines in one context as well as to hold steady Rawls's manner of arguing for it in another. Both contexts have their distinctive importance.

In elucidating what he means by 'reasonable,' Rawls does not "define the reasonable directly," but specifies "two of its basic aspects as virtues of persons." 23 [emphasis added] The first "basic aspect of the reasonable ... is the willingness to propose fair terms of cooperation and to abide by them provided others do." ${ }^{24}$ Rawls makes it clear that he is not asking people to be suckers. The norms they propose they honestly must believe are "reasonable for everyone to accept and therefore are justifiable to them ...." 25 And they are prepared to reason with others about them. They are open to the various norms being so proposed and take it as something that must also be open to reasonable others. (Those who are not so open will not in that crucial sense count as 'reasonable.') They must, as well, if they are reasonable, be prepared "to discuss the fair terms that others propose." ${ }^{\prime 6}$ They have the idea that the reasonable is an element of the idea of society as a system of fair cooperation and that its fair terms must be those that are reasonable for all to accept and that they indeed generally will be accepted in liberal societies. This is a crucial part of our very idea of reciprocity. ${ }^{27}$ If these conditions are violated, the practice of reasoning together reasonably is off. Someone committed to reasonableness should not make a sucker out of herself or just take the badgering of the unreasonable.

The second basic aspect of 'the reasonable,' and the most important aspect for the restrictions Rawls puts on the types of claims to be utilized in his distinctive defence of political liberalism, "is the willingness to recognize the burdens of judgment and to accept their consequences for the use of public reason in directing the legitimate exercise of political power in a constitutional regime." ${ }^{28} \mathrm{We}$ need to get clear about what Rawls calls the burdens of judgment, and why it is so important for him, including why it is so important in the rationalization of the limitations he puts on the kinds of arguments we can rightly deploy in arguing for the coherency and plausibility of political liberalism. As background to this, we need to note "two general facts about the public culture of a democratic constitutional regime: regimes which prominently include a political liberalism.

23 John Rawls, Political Liberalism (New York: Columbia University Press, 1993) at 48 [Rawls, Political Liberalism].

24 Ibid. at 54.

25 Ibid. at 49 .

26 Ibid.

27 Ibid. at $49-50$.

28 Ibid. at 54. 
They are, first, the fact of reasonable pluralism and second, the fact that this diversity can be overcome only by the oppressive use of state power." ${ }^{29}$

We need to ask why, if we just carefully, honestly, and persistently use with one another all our fairmindedness, all our intelligence, and our good will, we will not invariably end up in reasonable agreement. Why is what Kierkegaard called Socratism, namely, the belief that all problems have a solution if we just reason about them hard enough and carefully enough not true? Why are the rationalistic assumptions that motivated rationalist philosophers from Plato to Spinoza not achievable? Why is such reasonable argument among philosophers and other intellectuals so motivated, not something that will usually lead to agreement? Why is it that reasonable persons with integrity, intelligence, and good will still will find agreement often so illusive over the above matters and matters like them? Rawls's explanation of this is crucial for his treatment of political liberalism and for the justification of the restrictions that, he has it, are to be made by liberals in political arguments of the sort in which he engages.

Reasonable persons, Rawls contends, are persons who have realized what he calls their two moral powers: namely, an understanding of and a capacity for justice, and an understanding of and a capacity to achieve their own rational good. With such a realization of their two moral powers, they, Rawls has it, are free and equal when they are in a constitutional regime and "have an enduring desire to honour fair terms of cooperation and to be fully cooperating members of society." ${ }^{30}$ They share, according to Rawls, a common human reason. That is to say they have "similar powers of thought and judgment: they can draw inferences, weigh evidence and balance competing considerations." ${ }^{31}$ Yet, try as they will, they often cannot reach agreement over ultimate or crucial matters. They have not been able to do it in the past, and there is precious little reason to believe they will be able to do it in the future.

It is here where Rawls's conception of the burdens of judgment comes into prominent play. We speak here of the sources and causes of disagreement between reasonable persons, namely persons who have the two aspects of the reasonable person as basic aspects of their virtue as persons. The account of these burdens must be such that they are fully compatible with, and so do not impugn, the reasonableness of those who disagree over such matters. They can and will often disagree, and continue to disagree, and still remain equally reasonable by Rawls's minimal characterization of being reasonable; any tighter standards of reasonability would violate their acting in accordance with the burdens of judgment.

What are these burdens of judgment and why are they regarded as so important by Rawls? The "sources of reasonable disagreement - the burdens of judgment - among reasonable persons are the many hazards involved in the correct and conscientious exercise of our powers of reason and judgment in the ordinary course of political life." ${ }^{\prime 2}$ Rawls goes on to remark:

29 Ibid.

$30 \mathrm{Ibid}$ at 55.

31 Ibid.

32 Ibid. at $55-56$. 
As reasonable and rational we have to make different kinds of judgments. As rational we have to balance our various ends and estimate their appropriate place in our way of life; and doing this confronts us with grave difficulties in making correct judgments of rationality. On the other hand, as reasonable we must assess the strength of peoples' claims, not only against our claims, but against one another, or on our common practices and institutions, all this giving rise to difficulties in our making sound reasonable judgments. In addition, there is the reasonable as it applies to our beliefs and schemes of thought, or the reasonable as appraising our use of our theoretical (and not our moral and practical) powers, and here too we meet the corresponding kinds of difficulties. ${ }^{33}$

Rawls lists the more obvious of these sources of reasonable disagreement. They are all sources of difficulties in arriving at agreement in judgment and yet they are sources compatible with those judging being in Rawls's minimal sense fully reasonable. Disagreement in such contexts can, and typically will, be reasonable. They can indeed even be compatible with everyone's being fully reasonable in Rawls's minimal sense. The six sources listed by Rawls are as follows:

a. The evidence - empirical and scientific - bearing on the case is conflicting and complex, and thus hard to assess and evaluate.

b. Even where we agree fully about the kinds of considerations that are relevant, we may disagree about their weight, and so arrive at different judgments.

c. To some extent all our concepts, and not only moral and political concepts, are vague and subject to hard cases; and this indeterminacy means that we must rely on judgment and interpretation (and on judgments about interpretations) within some range (not sharply specifiable) where reasonable persons may differ.

d. To some extent (how great we cannot tell) the way we assess evidence and weigh moral and political values is shaped by our total experience, our whole course of life up to now; and our total experiences must always differ. Thus, in a modern society with its numerous offices and positions, its various divisions of labour, its many social groups and their ethnic variety, citizens' total experiences are disparate enough for their judgments to diverge, at least to some degree, on many if not most cases of any significant complexity.

33 Ibid. at 56. 
e. Often there are different kinds of normative considerations of different forces on both sides of an issue and it is difficult to make an overall assessment.

f. Finally, as we note in referring to Berlin's view, any system of social institutions is limited in the values it can admit so that some selection must be made from the full range of moral and political values that might be realized. This is because any system of institutions has, as it were, a limited social space. In being forced to select among cherished values, or when we hold to several and must restrict each in view of the requirements of the others, we face great difficulties in setting priorities and making adjustments. Many hard decisions may seem to have no clear answer. ${ }^{34}$

It is easy to see why, under such conditions, disagreement among reasonable people will obtain, and repeatedly obtain and to see as well how reasonable people will often agree to disagree. As much as some of these matters over which they differ and agree to differ mean to them, they will be tolerant (hard as it may be sometimes) of even deeply different and sometimes antagonistic views. They will be tolerant where those holding such deeply divergent views from theirs will themselves be tolerant of other deeply divergent views including theirs. Rawls goes on to remark:

Religious and philosophical doctrines express views of the world and of our life with one another, severally and collectively, as a whole. Our individual and associative points of view, intellectual affinities, and affective attachments, are too diverse, especially in a free society, to enable those doctrines to serve as the basis of lasting and reasoned political agreements. Different conceptions of the world can reasonably be elaborated from different standpoints and diversity arises in part from our distinct perspectives. It is unrealistic - or worse, it arouses mutual suspicion and hostility - to suppose that all our differences are rooted solely in ignorance and perversity, or else in the rivalries for power, status, or economic gain. ${ }^{35}$

It is an inescapable fact that many of our most important judgments are made under conditions where it is not to be expected that conscientious persons with full powers of reason, even after full and free discussion, will arrive at the same conclusion. Socratism or rationalism is simply not on the agenda. Some conflicting reasonable judgments (especially important are those belonging to people's comprehensive doctrines) "may be true, others false; conceivably all may be

34 Ibid. at 56-57.

35 Ibid. at 58. 
false." ${ }^{36}$ Indeed, I would add that some may arguably be incoherent. But there will be little agreement on which of these things are which. Rawls goes on to add the significant political liberal point that "these burdens of judgment are of first significance for a democratic ideal of tolerance." 37

Remember that Rawls takes as the second part of being reasonable "recognizing and being willing to bear the consequences of the burdens of judgment." 38 This is crucial for the way Rawls structures his conception of political liberalism and for the constraints required of political liberals over political matters. However, reasonable persons, if they affirm any at all, affirm only reasonable comprehensive doctrines. Reasonable comprehensive doctrines for Rawls have three main features. Firstly, as an exercise of theoretical reason a reasonable doctrine "organizes and characterizes recognized values so they are compatible with one another and express an intelligible view of the world." ${ }^{39}$ Secondly, they also single out, each in its own way, which values are "to count as especially significant and how to balance them when they conflict ...." 40 In this way there is also an exercise of practical reason. Thirdly, a reasonable comprehensive doctrine "normally belongs to, or draws upon, a tradition of thought and doctrine," though from this it does not follow that it is fixed and unchanging..$^{41}$ Traditions, we need to remind ourselves, normally change. And arguably they not only change, but also evolve and do not change arbitrarily and without explanation..$^{42}$ Doctrines with these three features are present in "the major religious, philosophical, and moral aspects of human life in a more or less consistent and coherent manner." ${ }^{43}$

Rawls is centrally concerned with not excluding doctrines except where they are clearly incompatible with his minimal concept of 'the reasonable' itself. "We," he puts it, "avoid excluding doctrines as unreasonable without strong grounds based on clear aspects of the reasonable itself." ${ }^{44}$ The thing is to bend over backwards to avoid being arbitrary and exclusive and, above all, to avoid being partisan.

He then makes a set of remarks, including a crucial but little noticed remark in footnote 13 of page 50 in his Political Liberalism, ${ }^{45}$ that is crucial for the case I have been trying to make about the compatibility of Rortyian-reasons and Rawlsian-reasons. In the passage with which I am principally concerned, Rawls remarks in the body of his text, "Political liberalism counts many familiar and traditional doctrines - religious, philosophical, and moral - as reasonable even though we could not seriously entertain them for ourselves, as we think they give excessive weight to some values and fail to allow for the significance of others. $A$

\footnotetext{
36 Ibid.

37 Ibid.

$38 \mathrm{Ibid}$. at 58-59.

39 Ibid. at 59.

40 Ibid.

41 Ibid.

42 Alasdair MacIntyre, Three Rival Versions of Moral Inquiry (Notre Dame, IN: University of Notre Dame Press, 1990).

43 Rawls, Political Liberalism, supra note 20 at 59.

44 Ibid.

$45 \mathrm{Ibid}$. at 50, n. 13.
} 
tighter criterion is not, however, needed for the purposes of political liberalism." 46 [emphasis added] This passage then refers us to footnote 13:

Certainly, comprehensive doctrines will themselves, as they present their case in the background culture, urge far tighter standards of reasonableness and truth. Within that culture [which is not a part of public reason] we may regard many doctrines as plainly unreasonable or untrue, that we think it correct to count as reasonable by the criterion in the text. That criterion we should see as giving rather minimal conditions appropriate for the aims of political liberalism. ${ }^{47}$

And we should recall that the aims are certain distinctive political aims, and these aims are to articulate a coherent conception of political liberalism that all reasonable political liberals -reasonable in the minimal sense that Rawls deploys for these purposes - can agree on even where they are holders of very diverse comprehensive doctrines or no comprehensive doctrines at all. Yet they must be views that by Rawls's minimal criterion of reasonability count as reasonable. No stricter criterion can justifiably be invoked for this purpose. This is all we can expect or indeed have and all we need to attain political agreement among political liberals in our present-day intractably pluralist societies. But this is sufficient-or so Rawls argues-to attain civility and political justice: deeply democratic political justice in our societies. And this is his aim, and, keeping firmly to it, he sticks with playing that language - game, adhering to the cluster of practices, we have characterized him as playing. But these are not the only aims, the only language-games, that political liberals can play and play in the service of political liberalism. Sometimes in some situations it is important, in politically arguing, and indeed politically arguing about justice, to deploy a stricter criterion of reasonability for political justice.

I am thinking here of places where we could and should use tighter standards than those we employ in the political contexts Rawls is discussing for the internal justification of political liberalism. I conjecture that in his footnote thirteen he was thinking of discussions in seminars, first class media contexts, intellectual debates in various public but non-state contexts and in private discussions. In all of these contexts there is no question of parliamentary, legal, or other governmental decisions being taken. They can, of course, influence these decisions, but they are not part of the deliberative process where such decisions are made. Where such political decisions are at issue, at least in most such contexts, I think it is obvious that in a liberal society or indeed in any decent complex society that Rawls's minimal criterion of reasonability should be adhered to. However, there are other public discussions and debates, such as those mentioned above, that are designed to enlighten and not directly to lead to governmental or otherwise practical decisions either challenging or supporting the government. I think these public discussions should use a tighter criterion of reasonability. I shall argue

46 Ibid. at 59-60.

47 Ibid. at 60. 
that there are contexts, indeed political contexts, in which tighter standards of reasonability in discussions or debates are in order. These might very well include writings, discussions, debates that have an indirect effect, and indeed sometimes a relevant effect, on decisions taken in Parliament and the like. However, when a vote is to be taken and the debate is in Parliament then Rawls's minimal criterion must - morally speaking 'must'- rule the day. The same is so for court decisions or state executive decisions. But in discussions, writings, debates leading up to the debate before the discussion and voting in parliament, tighter criteria than what Rawls uses for political liberalism are often to be used. However, in the context of the actual debate in parliament concerning what governmental decision to make, the minimal criterion of reasonability must prevail, along with public reason. This should be partly definitive of what is to count as being a politically liberal society. Discussions in a seminar are one thing and debates in Parliament are another. The former should use a tighter criterion of reasonability than the latter.

To illustrate the rationale for what I have been claiming, we might consider the proposal to make same-sex marriage part of the law of the land - a debate we have actually had in Canada in 2005 and South Africans had in their country in 2006. But it could as well have been about abortion, drugs, contraception, and in times past (or in places like Chile, time present) divorce. But debates about same-sex marriage are current, often heated, and taking place not only in Canada and South Africa but also in other liberal democracies. I shall use same-sex marriage as an example to make my point concerning when for political liberalism a minimal criterion/criteria of being reasonable must be employed and when it should not, or at least need not.

Suppose a Parliamentarian speaking in parliament in such a debate gets utterly out of line and says, 'We can by no means accept such gay and lesbian cohabitation as marriage, no matter how long and steady their relations have been, for homosexuality is a disgusting, loathsome, and sinful practice that can by no means be tolerated (not to speak of its being sanctified by marriage). Homosexuals should be imprisoned or, if we can bring back the death penalty, executed. Burning lesbians at the stake, though utopian, would not be inappropriate.' His or her remarks - remember such a person is speaking in Parliament - should be firmly reproved and simply ignored in the subsequent debate in Parliament. But his or her basic point could be put in a milder form. It is, after all, a hyped-up expression of what by Rawls's own account, using his minimal criterion of 'the reasonable,' is a reasonable comprehensive view of the good even in present day politically liberal societies. And remember Rawls reminds us that in "a particular case someone may, of course, hold a reasonable doctrine in an unreasonable way .... That does not make the doctrine as such unreasonable. A reasonable doctrine is one that can be affirmed in a reasonable way." ${ }^{88}$ Suppose another Member of Parliament [MP] with the same general views (homosexuality is against God's law) rises in Parliament to say that though his colleague's expression was, to put it mildly, explosive and to many deeply offensive, still, after all, homosexuality is a sin against God's law and should not be acknowledged as something mor-

48 Ibid. at 60, n. 14 
ally acceptable, let alone sanctified by something that the law being voted on here would, if passed, publicly acknowledge, at least from a legal perspective, homosexuality as being morally acceptable. His view, expressed in that way, is a view that by Rawls's minimal criterion would be regarded as part of what counts as a reasonable comprehensive view. ${ }^{49}$ Yet it would carry no weight with most liberals. It would be regarded by many, perhaps most, people as an absurd and rather antique view that we would be well to be without; in so reasoning they are at least implicitly using a stricter criterion of reasonability. But the second Parliamentarian's claim expressed as he put it could legitimately be entered into the parliamentary debate using the minimal criterion. Though his claim would have little weight with his more secular-minded colleagues in debate over the proposed law, it still should in turn be pointed out that it is not just a matter of a group of more or less secularly minded political liberals ganging up on certain religious people; for the proposed law, if passed, would plainly not force such a religious person or his church to accept, let alone practice, gay or lesbian marriage. 'It's the law of the land,' they must acknowledge (if the bill is passed), but they need not (and this is, of course, compatible with the proposed law) become gays or lesbians or accept them in their religious community and their clergy need not marry them. To argue, as some might, that they must if requested, marry them would violate the conception of tolerance and respect for persons which Rawls and which liberals generally regard as central to liberalism. Moreover, such antique views expressed in the way the second orthodox religious MP expressed them should be allowed into the debate. But in a liberal ethos they would have little influence in parliamentary debate. Moreover, the MP and people with his mindset should be reminded that no one is being required or urged to be gay

49 John Rawls, "Idea of Public Reason Revisited", in Freeman, supra note 10, 573 at 574-615. Boran ignores this distinction between Philosophy and philosophy (See Boran, supra note 1). But I (pace her understanding of me) argue for an anti-Philosophy philosophy. (See Nielsen, "Anti-Philosophy", supra note 12). I eschew Philosophy (metaphysics, epistemology, meta-ethical theories, normative ethical theories, and normative political theories) not philosophy with its reflective and critical activity, not as Boran puts it by saying "that philosophical reflection should be abandoned in order to be replaced by practically viable forms of thinking" (Boran, supra note 1 at 269). Surely the Sellars's conception of philosophy endorses a thorough reflective orientation. Moreover, it is something as old as the hills and is not something that with anti-Philosophy

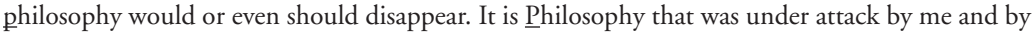
Rorty, not philosophy. Neurath in good logical positivist fashion did not appeal to metaphysical views any more than did Rawls in his articulation of political liberalism. The philosophy Neurath appealed to and utilized was philosophy. What Boran calls normative naturalism is much the same, if not identical with, what I have called social naturalism (Nielsen, Naturalism, supra note 12 at 25-55). Neither of these doctrines is metaphysical nor, I would argue, make epistemological claims. They all travel Philosophically light while remaining attempts to see how things in the broadest sense of the term hang together in the broadest sense of the term. This is certainly to be reflective and to be reasonably systematically so, but it need not, and in my view should not, commit one to Philosophy. In that way it remains deeply anti-Philosophical while still being philosophical. Boran is right in saying that WRE is a procedure but WRE is also not without an appeal to substantive matters. After all, as Rawls uses it, and as I do, it collects together and utilizes considered judgments. They are matters that are surely substantive. Rawls is insightful here in his reply to Habermas. See John Rawls, Political Liberalism, (New York: Columbia University Press, 2005) at 421-433. 
or lesbian, no one in his congregation is being required to perform such marriages, gays and lesbians could even be expelled - or excommunicated - from the church of which he/she is a member and 'true believers' could shun their company. But, as the argument goes, the legal right to marry should be extended to such persons, and they should also have the right to the same public presence as other people, e.g., to teach, to practice medicine, to run for office, to themselves perform marriages if they are (as they can be) in a legal position to do so and the like.

Such a religious person may shun them, it is sad to contemplate, but they may not be publicly shunned: their legal, political, and social status should remain the same as that of others. There is no possibility of that not being so in a genuinely liberal democracy. (Indeed this is a matter of definition.) Moreover, there are many things we have a moral right to do - such as shunning them - that we should not do. So nothing is being forced on the person with such conservative religious views except to accept, should the legislation be passed, the equal legal, political, and social status of persons he disapproves of because of their particular views concerning homosexuality and because of their own sexual orientation. Persons who have not committed any crime in what is acknowledged as such by law in the liberal society of which he or she is a member cannot be persecuted or legally discriminated against for having the sexual orientation they have.

To the response that homosexuality should be made a crime, the reply is that it is not a crime, at least in liberal societies. And in societies such as ours there is certainly no consensus on whether it should be made a crime, and to make it a crime, in any society, would show contempt, or at least a lack of respect, for people with a certain sexual orientation and thus violate one of the deepest commitments of political liberalism, namely respect for persons (all persons) where they have done nothing to harm others. A political liberal could not vote that it be made a crime and still remain a political liberal anymore than she could accept apartheid and be a political liberal. It denies respect for persons which is central to liberalism.

Here, it might be argued, we have considerations which must be backed up with tighter standards of reasonability than Rawls wishes to deploy for his internal arguments for political liberalism. But it should in turn be replied that his minimal standards are sufficient for such an argument. They are considerations that all liberals can rightly acknowledge in the face of what actually comes to, even when not so intended, an illiberal assault on liberalism.

Political liberals are in all sorts of situations, where they have different ends in view than Rawls's, where they can make non-question begging arguments in response to illiberal alternatives to liberalism of an extensive range of topics, e.g., ethnic nationalist or authoritarian assaults. There is no place, in the face of such critiques, where we must say that nothing further can be relevantly said and that our spades are turned and that is that. However, in spite of what I said above, it looks like there are places - emotionally charged places such as gay-marriage and abortion - where perhaps political liberals cannot, when pushed, proceed just in terms of Rawls's minimal account of reasonability but must appeal to tighter standards. This seems to be so even in parliamentary debate where public reason should rule the day and even more obviously so in the public forum of civil so- 
ciety in arguing the case for legalizing gay marriage. Arguably, there is over such issues sometimes, perhaps even often, a need to appeal to a tighter criterion.

I want to argue now that this is not so evident as it might at first seem. Let us go back to our moderate, mild mannered, perhaps just small - conservative parliamentarian. He reminds us that homosexuality is a sin. However, becoming more conciliatory, he reminds us - and more appropriately - that it is so regarded in his church - a church which has many members, some of whom regard themselves as political liberals - quite unequivocally taken to be a sin. Suppose in parliamentary debate a secular-minded Russell-admiring MP, following Russell, remarks that 'sin' is not a term that is a part of his vocabulary or conceptual scheme. The mild mannered conservative retorts that for many sincere, conscientious, and sometimes even reflective religious believers, 'sin' is very much a part of their vocabulary; and there are even certain denominations - Catholic, some Protestant, some Jewish and Muslim - that regard homosexuality as a sin; and for some denominations their adherents must believe it to be a sin on pain of apostasy. (Of course, for the Russellian MP, 'apostasy' will also not be a part of his vocabulary.) To the question 'Why it is sinful?' the mild mannered but orthodox believer will retort that it harms people and rends the fabric of society by making life unstable, undermining the family and family values.

The debate, if not in the Parliament then at least in the parliamentary restaurant, will go on probably in predictable ways. The defender of the acceptability of homosexuality and of the proposed law that gays and lesbians be given same-sex marriage rights will argue that homosexuality does not harm people or at least that there is no good evidence that it does, but what clearly does harm people is discrimination, non-recognition, exclusion, and not to be afforded equal citizenship rights or human rights. This in turn will generate the response that it does harm people in other ways. It impedes their psycho-sexual development. Instead of going for treatment, homosexuals, being accepted in society, may even come to be role models for some. Some children, finding them as role models, may have their psycho-sexual development impeded. The moderately orthodox religious MP, if he is reasonably knowledgeable, may point out that even some psychoanalysts, heirs (among other things) of Freud's firm atheism, think that homosexuality is harmful, making it impossible for homosexuals to have a 'genital personality' and thus making it impossible for them to become mature, or at least optimally mature, persons.

Most secularly minded persons (and indeed some religious persons) will think this all nonsense and indeed harmful nonsense. However, mindful of the burdens of judgment, our Russellian MP might say to his mildly orthodox conservative colleague, 'Look you and I are not going to agree about homosexuality, and, most particularly, that it is a good thing that the institution of marriage be extended to homosexuals, but we do agree about the deep democratic and liberal value of people being treated with equal respect. That is a deeply shared element in our common liberal view. Just as blacks and whites were not treated with equal respect under apartheid or Jewish and Arab-Israeli citizens are not being treated with equal respect in Israel, so homosexuals and bi-sexual citizens in our society are not treated with equal respect and do not, where the proposed law is not passed, even have equal rights. And you and I as democrats and political 
liberals cannot accept that.' The moderate conservative liberal-leaning MP may rather reluctantly come to accept that argument just as some liberal Catholics have so reacted to the abortion debate. And, if that is so, debate can be conducted and settled in terms of Rawlsian minimalism, WRE, and an appeal to public reason.

However, faced with the above argument, the conservative, but still politically liberal, believer, may stiffen his back and respond, 'As much as I care about equal respect for people and equal citizenship rights and liberal democracy, I will not - indeed morally speaking I cannot - set aside or go against the ex cathedra proclamation of my church, now frozen into doctrine, namely that homosexuality is a sin, anathema to my faith, which requires that homosexuality, a grave sin, must be categorically rejected and never sanctified legally or otherwise. I agree that that doctrine does undermine equal self-respect and equal citizenship. That deeply distresses me. But the Pontiff speaking ex cathedra condemns homosexuality and gay marriage categorically. I must believe as a Catholic that what is so proclaimed is absolutely true and categorically must be accepted and must be acted in accordance with. I cannot keep my faith and reject that. And my faith is of overwhelming importance to me. My spade is turned. I can do no other.' The Russellian MP may feel that his spade is turned too. He may very well feel that there is no more room for further argument and discussion. But he can also see that the conservative MP is acting in good faith and is, by Rawls's minimal criterion of reasonability, being reasonable.

If dialogue is to go on - if they are to get their spades out of the ground - it seems at least that they can no longer rely just on Rawlsian reasons, which travel philosophically light. They have to turn to considering challengeable and deeply challenged world-views. But in a stronger sense of 'reasonable' these things can and should be argued. However, perhaps surprisingly and perhaps counter-intuitively, I shall argue that this is not so. I do not deny that, in a stronger sense of 'reasonable,' that these things can be argued. What I deny is that, for political and legal purposes in a politically liberal society, they need to be and should be so argued. We can and should stick with our minimal criterion of 'reasonable.' Am I just stamping my feet?

However, there remain two considerations that should be faced. The first one fits with the overall argument I have been trying to make and the second one ends in a jarring note that I take to raise important considerations to which I do not yet (perhaps I never will) know how to respond. The first consideration claims that the moderate but orthodox believer, wishing to be a political liberal, cannot be one, or at least cannot be a consistent one, if he takes the turn I have just put in his mouth. However, he cannot, it is being claimed, consistently be a political liberal and have the faith he has. He must choose to be consistent. As important as liberal values are to him, he (given his faith) is committed and believes he must remain committed to allowing ex cathedra religious doctrines to override his politically liberal beliefs where they conflict. He, that is, abandons his political liberalism where it comes (as it sometimes does) into conflict with such doctrines of his faith. He cannot be a consistent political liberal and have the faith he has. However, this is not true if he accepts, within the bounds of political liberalism, a democratic vote to be overriding even when it runs against 
what his faith deeply commits him to do. His so acting democratically (accepting the vote) does not require him personally to approve of gay marriage or to go against anything which the Pope says when he is speaking ex cathedra. Rather, he is free to accept the vote, in a politically liberal parliament, while remaining free to continue to dissent. He continues to think the Parliament has made a grave mistake. But he finally bows, as all democrats must, to the will of the majority where a clear violation of human rights is not at issue. ${ }^{50}$ But he keeps faithful to his own conscience and his own personal way of viewing things and responding to them, e.g., a Catholic priest will not marry gays but accepts, if so goes the vote, that it is the legitimate law of the land and that others may do so. (Is this to say, when push comes to shove, democracy is to outweigh any religious orientation? For a liberal, yes. Is this just stamping one's feet for liberalism? )

The second observation is the more glaring and jarring one given my account. Suppose a religious person (while remaining devoutly religious) accepts certain key political matters (e.g., same-sex marriage) as valid legislation when it gets a majority vote in legislature. She accepts this, let us further suppose, as trumping in that domain whatever her faith categorically commits her to. Can, given her faith, she consistently do so? I have come rather ambivalently to think so. However, even if she can consistently do so, and that is what a politically liberal democratic society comes to require, will it not then be the case - indeed cannot but be the case - that in a deeply pluralistic, modern, extensively secular liberal society, with its embedded political liberalism, that religious views, where they sit uneasily with the orientation of such a society (as they do), will be marginalized? (But to be marginalized is not to be excluded.)

Central as such religious convictions are for the faithful to such a religious orientation and no matter how much they are a part of the web of (politically speaking) the lives of these religious persons, they will have to be trumped in a politically liberal society, and indeed inescapably, where they conflict with what is central to political liberalism and entail a policy (as they do) which is in deep conflict with it. This is indeed crucial for political liberalism. But is this not, when all is said and done, if that ever is so, to just insist on political liberalism - a kind of stamping one's feet - and is not that itself not to show respect for such religious persons? Maybe things are more complicated than I have made them out to be? Or than Rawls takes them to be? And does this not make difficulties in WRE when it is taken as a method for rationalizing political liberalism?

Maybe we need some foundational beliefs? And indeed, where there is more than one, for them to be hierarchically or lexically ordered. But can that be

50 The politically liberal conservative might respond that such a vote violates human rights. Political liberals, he might continue, can no more make that a 'vote issue' than they can make genocide or slavery a 'vote issue.' Not everything is a vote issue where we (if we are democrats) must bow to the will of the majority. We, while remaining democrats, cannot vote on genocide or anything that violates what is plainly a core human right. But accepting gay marriage is not a violation of human rights. Gay marriage is within the bounds of political liberalism while genocide is not. But suppose the Pope, speaking ex cathedra, says that gay marriage is a violation of human rights. Does this make it so? Must our conservative political liberal then accept that? Can the Pope, speaking ex cathedra, say that $2+2=5$ ? Must the conservative political liberal so crucify his intellect if the Pope proclaims that ex cathedra? Perhaps he must? 
compatible with a genuinely political liberal view or with modernity? Or even with careful philosophical thought? Is it to ignore what we have learned from Wittgenstein, Neurath, Quine, Sellars, Davidson, Kuhn, Rorty, Brandon and Michael Williams.? What to say here is not obvious to me. Perhaps we should stick with a consistent fallibilism and acknowledge that even respect for persons, as morally central as it is for us, should not always be the overriding value, as no value should have such a status? Nothing should be unconditional. Sometimes respect for a person or persons A conflicts with respect for a person or persons B. Or so at least it seems? This being so we must look elsewhere for what is to guide us in such a situation. But even this is not evident. We must take to heart the lesson that we never get unconditionality and that over matters, such as discussed above, it is seldom, if ever, that we even get decisiveness. Even, unpalatable as this sounds, respect for persons is sometimes up for grabs. We see that even here we do not get unconditionality - no place where we must stop, where there is something which we categorically must do. This is hard for us to accept - almost humanly impossible for us to accept. Yet is this not what, if we can hold on to our brains, we must conclude? Rationalism as well as traces of religiosity dies hard with us. And there is no 'Big Daddy' up there in the sky to save us. We can accept this and still ask what we are to do as believers in equal self-respect for everyone, where respect for A conflicts with respect for B and the conflict is ineradicable. But again, is this ever actually the case? I don't know. But, if it is, what should be done? Or are we, in typical philosophical fashion, making up artificial puzzles for ourselves?

To sum up, Rawls and Rorty both, and I as well, are concerned to defend political liberalism and, in doing so, to deploy WRE. ${ }^{51}$ All three of us think that in engaging in that task, we should set aside metaphysical, epistemological theories and any attachment, at least where political liberalism is at issue, to any particular comprehensive theory of the good. We want in that respect to travel Philosophically light. In employing WRE all three of us consistently stick with its basic procedures. We sometimes in defending political liberalism appeal to different substantive considerations - different reasons - in equilibrating and we have partially different aims in defending it. These reasons are thought not only to be different but some think they are conflicting. This I argue is mistaken because our different WREs are constructed for different purposes. Rawls seeks to give an internal justification for political liberalism by showing how its considered convictions and beliefs consistently and coherently (if this does not come to the same thing) hang together. Rorty and I seek that too. But we also seek to give an external justification for political liberalism by giving reasons that challenge the counter claims of illiberal (as well as other non-liberal political accounts) and, as well, give additional reasons other than those showing consistency and coherency for political liberalism that challenge non-liberal views. Rawls shows how political liberalism, which has often been thought to involve conflicting claims, can be articulated in such a manner as to show that it is

51 I should add parenthetically, so as to not confuse people who know my work, though I will not try to explain it here, that this is perfectly compatible with my socialism. I have at times, somewhat paradoxically, but as I see it perfectly consistently, characterized myself as 'a liberal communist.' 
a coherent and attractive view that can make sense of the most fundamental considered convictions of political liberals as well as many others. It can be set out without conflicting views. He does not try to show how those non-liberal considered convictions that conflict with those politically liberal considered convictions - substantive and not purely procedural convictions-can be responded to by political liberals other than by being ignored. Both Rorty and I argue that it is important to show the superiority of political liberalism to illiberal and other non-liberal views and how we can use WRE to do so in a way that is different from, though non-conflicting, with Rawls's position. Rawls, in short, gives an internal justification of political liberalism while Rorty and I give as well an external justification of political liberalism. Both are legitimate even if different activities. But neither are sufficient without the other for a thorough defense of political liberalism.

\section{ADDENDUM}

One of my anonymous referees argued that Rawls, by showing that political liberalism is internally coherent - can overcome certain internal tensions such as a belief that we cannot have both autonomy and equality does make a contribution to answering illiberals since one of the reasons for not accepting political liberalism is the belief that there is, and can be, no coherent political liberalism: that some of the tensions in political liberalism come to contradictions. If Rawls has shown, that political liberalism can be characterized such that it is a coherent position, then one familiar reason for rejecting political liberalism and adopting a non - liberal position has been undermined. The illiberal can no longer claim that political liberalism is to be rejected, because it has been shown to be contradictory or incoherent.

I think this point is important and well taken. However, it only disposes of one argument for rejecting political liberalism. An illiberal - say, an authoritarian meritocrat - could accept the coherence (consistency) of political liberalism and respond that its main difficulty is not its coherence but that it rests on manifestly, absurdly false premises. It, for example, believes, and indeed centrally, in human equality and equal respect for all people. But, an illiberal will maintain, people are clearly unequal. There are people, as Sarkosy put it, who get up early and work hard and contribute something to their society and then there are the couch potatoes or the chaps who go to the bar as soon as it opens and stay for hours chewing over with their mates the local news and gossip. The authoritarian meritocrat will say, reflecting on examples like that, examples which abound, 'Don't talk to me about the equal worth of people or that all humans, just by being human, deserve equal respect. Just look around and see how people are.' I think such claims need to be answered and can, indeed rather easily, be answered. I have attempted to answer them. ${ }^{52}$ But the point is that they need to be answered. There are a multitude of such arguments available to the illiberal or

52 Kai Nielsen, Equality and Liberty: A Defense of Radical Egalitarianism (Totowa, N.J.: Rowman and Allanheld, 1985) at 29-38, 103-190; See also Brian Barry, Why Social Justice Matters (Cambridge, U.K.: Polity Press, 2005). 
non-liberal or the neo-conservative. Showing the consistency and coherence of political liberalism is important but by itself it will not suffice to justify political liberalism.

The same referee goes on to claim that the particular way I go about answering the illiberal seems at least to conflict with the assumptions of Rawls's political liberalism. I think his assessment of me has considerable force. It is fair and often perceptive. I want to quote it in full rather than rely on my paraphrase. $\mathrm{He} / \mathrm{she}$ remarks:

Nielsen's response to the illiberals mentioned above involves denying the possibility of foundationalism, asserting instead a historicist, finitist, and fallibilist epistemology that is allegedly inconsistent with the illiberal views in question. "We cannot escape assuming this or some other contestable philosophical position in arguing with this assortment of illiberals," Nielsen contends. Thus he concludes the paper by arguing that "neither the fascist nor the liberal nor anyone else, can get the superior vantage point our fascist claims for himself," again invoking Rorty's historicism and contextualism. If the fascist is reasonable, he can come to see the force of the better argument, and realize that 'we are all without - except as ideological illusions-such skyhooks, such an Absolute perspective". If such arguments ought to force a fascist to recant, and acknowledge liberalism, it must be because one renounces some kind of perspectival - ism. But isn't Nietzsche in some sense a nonfoundationalist illiberal? If so, antifoundationalism is not a sufficient external defense of liberalism. Conversely, the premise of Rawls's political liberalism, and of his political deployment of WRE, is that one can be a foundationalist liberal. If so, it is not necessary for the external defense of liberalism to appeal to antifoundationalism. A foundationalist liberal could simply challenge the truth of the foundations to which the illiberal appeals, arguing in favour of other foundations. God fully approves of homosexuality, a religious liberal might say, for example. Nielsen might respond that the foundationalist liberal simply employs "some other" philosophical position, to use a phrase, but then it's not clear why we need to respond to the illiberal by invoking antifoundationalism. By closely associating the external defense of liberalism with antifoundationalism, Nielsen puts into question whether one can in fact be a political liberal, if one believes in foundations.

This referee makes, in what I have just quoted, the following nine claims. I will state them and then examine them seriatum.

1. I, in effect, deny the possibility of foundationalism by asserting instead holism, historicism, finitism, and fallibilism. (I 
need not and do not regard them, any of them, as epistemological views. But this is a small point, mainly a matter of terminology. Regardless of however we characterize them, they are what Rawls would call controversial philosophical views.)

2. It is false to say that non-foundationalist views must be liberal. Nietzsche is a glaring counter - example and I (Kai Nielsen) would add that he is by no means alone.

3. We cannot escape perspectivism, holism, historicism, contextualism, and fallibilism. We must all come to see, if we would be at all tough-minded, that we are without metaphysical skyhooks or indeed any kind of skyhook. No one, neither the political liberal nor the political anti-liberal nor an otherwise non-liberal has such an Absolute perspective such that they could with that refute the other. Indeed there is no such Absolute perspective. But to take this view, however strongly justified, is to take a Philosophical view.

4. Nielsen argues falsely or perhaps instead incoherently - but in either case mistakenly - that an anti-liberal, if he would be consistent, must, if he renounces foundationalism, end up becoming a political liberal.

5. If in point 4, I argue mistakenly, then anti-foundationalism is not a sufficient external defence of political liberalism.

6. Rawls consistently and plausibly is claiming that, as far as his account of political liberalism goes, one can be a foundationalist political liberal as well as a non-foundational or antifoundational historicist political liberal. Rawls, in defending political liberalism, does not appeal to any such metaphysical account nor does he need to.

7. A foundationalist political liberal could challenge the truth of foundational claims of anti-liberals and vice-versa.

8. It is not clear why we need to respond to an illiberal by invoking anti-foundationalism.

9. By tying (so my referee says) my defence of political liberalism to anti-foundationalism, I put, by my very own procedure, in question whether one consistently and plausibly can be a political liberal if one believes in foundations.

All of these claims raise anew the question of whether, unless I can successfully meet their challenge, I can have my Rawls and Rorty too. That is, whether Rawls's or a Rawlsian WRE and Rorty's or a Rortyian WRE are compatible. I think they are, but plainly this is problematical. Let me explain this dark saying. If we, as arguably (but perhaps mistakenly) we should, make a sharp distinction between internal and external defences of political liberalism, we perhaps can continue to consistently, or even plausibly, argue for the compatibly of the two WREs in the way I have. It seems plausible to do so. But Quine, Putnam, and Rorty prominently among others have raised problems about dichotomies. But 
dichotomies are one thing; distinctions, as Putnam has stressed, are another. ${ }^{53} \mathrm{I}$ shall continue to assume the viability of the distinction between internal and external justifications while acknowledging it might pose a difficulty for my account and that this issue needs investigation. But I shall not attempt to do that here. What I shall do instead is examine the nine claims taken from my referee's account one by one.

1. I accept the first claim, though it needs some interpreting, and 'the possibility of' should be understood as the 'plausible possibility of.' But, that aside, it does seem at least to point to two difficulties in my account. It sounds like I run into what Boran (following Jean Hampton and Joseph Raz) calls the self contradiction objection. ${ }^{54}$ In denying foundationalism, I appeal to historicism to reject all philosophical accounts. I, that is, use philosophy to refute philosophy. But there and elsewhere I use philosophy to refute Philosophy. ${ }^{55} \mathrm{I}$ am not, as Boran thinks, attacking philosophy. I advocate, as does Rorty, an anti-Philosophy philosophy. I reject Philosophy (metaphysical theories, comprehensive conceptions of the good, epistemological theories, foundational or non-foundational) but continue to do little $\mathrm{p}$ philosophy (reflection, critical analysis, and attempt to see how things hang together in the broadest sense of the term). This conception of philosophy as critical and reflective is as old as the hills, unproblematic, and atheroetical. ${ }^{56}$ It, unlike Philosophy, does not appeal in any way that Rawls would eschew to controversial Philosophical theories but to our reflective and critical capacity and activity (something widely practiced in our societies and not just

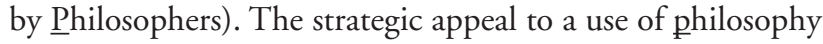
against Philosophy was practiced, though not so named, by G. E. Moore in his defense of common sense and by Charles Peirce in his critical commonsensism and by his relying at certain crucial junctures on what he called acritical beliefs. Neither practiced just philosophy nor did Wilfrid Sellars, but those particular appeals of theirs (and of Sellars) can be understood as a practice of the activity of philosophy in critiquing Philosophy. And it was Philosophy that both Rawls and Rorty were concerned to reject, or in Rawls's case (more modestly) to set aside when arguing for political liberalism. Both of them practiced philosophy but rejected Philosophy

53 Hilary Putnam, The Collapse of the Fact/Value Dichotomy and Other Essays (Cambridge, MA: Harvard University Press, 2002) at 9-11, 60-61.

54 Boran, supra note 1 at 265.

55 See supra notes $12 \& 46$.

56 Kai Nielsen, "Pragmatism as Atheoreticism: Richard Rorty" (2005) 2:1 Contemporary Pragmatism 1. 
or, less polemically in Rawls's case, by using the method of avoidance Rawls, eschewed Philosophy in defending political liberalism. This is what I had in mind by appealing to reflective commonsense, as Moore and Peirce did at certain junctures. I did this in deploying WRE. And to do this was to appeal to something substantive and not just procedural or methodological. So in Claim 1, so understood, I do not violate Rawls's constraints concerning any appeal to a Claim 1. So understood, I do not either violate Rawls's constraints concerning any appeal to a Philosophical theory to reject all Philosophical theories nor am I caught in the self-contradiction objection. Moreover, to appeal to commonsense here is to appeal to a substantive view and to claim, $a ́$ la Moore, of this defense of commonsense, that it is more certain than any Philosophical view that might oppose it. That is to say we can be more confident that boiling babies is extremely evil than any Philosophical, or for that matter philosophical, theory or activity used to deny, question, or defend it, just as we can be more confident that the world has existed for many years past than we can be of any theory concerning the external world.

2. Considering the referee's second claim, it is perfectly true that Nietzsche was a non-foundationalist and a fierce - indeed powerful - critic of liberalism. So were, though not as paradigmatically, Kierkegaard and those thinkers characterized by Isaiah Berlin as thinkers of the counter-enlightenment, including the romantic counter-enlightenment. The short of it is that I never claimed nor implied, nor gave to understand that all liberals were non-foundationalists and all non-liberals were foundationalists. On the liberal side, both John Stuart Mill and Kant were foundationalists and, to come down to our time, C. I. Lewis, Curt Ducasse, and Roderick Chisholm were liberals and foundationalists. The crucial thing that I am claiming concerning these matters is that political liberalism as well as non-liberalism can be non-foundationalist and without (even implicitly) any commitment to any acknowledged or even unacknowledged employment of foundationalist views.

3. I accept 3. Indeed, I would emphasize it. But this rather Rortyian move puts me, it might well be said, in conflict with Rawls. Let us, for short, call 3 a commitment to historicism. But would not Rawls regard it as another metaphysical (controversial philosophical view) that he, for the purposes of articulating and defending political liberalism, would avoid? I think he would, but he should not. Let me explain. Like Rorty, ${ }^{57}$ I regard Rawls himself, from at least his Dewey lectures,

57 Rorty, Objectivity, supra note 14 at 175-196. 
as a historicist though he does not so characterize or regard himself as such? But if we look at what he does, he is reasoning like a historicist. He sees, I believe quite correctly, political liberalism as a historical form arising at a certain time with certain historical beliefs that can be arranged in a coherent way and a political outlook that has a determinate rationale for certain people at a certain time and place and attuned to a determinate form of life. Political liberalism was not on the agenda a hundred years ago for a cannibal from the center of what is now called Papua New Guinea and it is not on the agenda today of the ruling Saudi hierarchy. Rawls is not interested in arguing for political liberalism's universal validity and does not critique or defend or examine in his defence of political liberalism any (in the traditional sense) metaphysical, epistemological, normative ethical or meta-ethical theories. His contractarianism is a device of representation and is not deployed in his defence of political liberalism nor is the constructivism of his Dewey lectures. Moreover, for him, as we have seen, justification is contextual. He does, as does anyone (Philosopher or not) who is reflective and critical minded, rather systematically reflect on and critically analyze things. (How systematically will vary from person to person.) That is, they do small $\mathrm{p}$ philosophy. But that is just to be reflective and critical minded and to try to grasp how things hang together. It need not - and in my judgment should not - be to set out a metaphysics or an epistemology in any traditional sense. Still, it will be responded, historicism is a controversial philosophical view. But if philosophical at all, it is a little $-\mathrm{p}$ philosophical view and not a big - P Philosophical view. Historicism, as I have not eccentrically characterized it, would not be something that the philosophical profession would take as a distinctively $\underline{P h i l o s o p h i c a l ~ d o c t r i n e . ~ I t ~ i s ~ s o m e t h i n g ~}$ that intellectuals of many or no discipline might assert or deny. But suppose, nonetheless, Rawls or a Rawlsian would continue to insist that historicism was a controversial philosophical doctrine. Then I would reply that it is a little $-\mathrm{p}$ philosophical doctrine that neither I nor Rawls nor anyone employing WRE need appeal to in giving an internal justification of political liberalism. Historicism can, when political liberalism is so at issue, be benignly ignored. But if an external defence is at issue where someone is defending an illiberal position claiming that political liberalism was either lacking foundations or had mistaken foundations while her illiberal position had sound foundations and that that was sufficient to warrant setting aside political liberalism, then historicism - the view appealed to in 3 - would be an important resource in an external justification of political liberalism. For many of 
us historicists, political liberalism is thought to fit nicely with historicism. But, as we have seen, the connection between political liberalism and historicism is contingent. Rawls does not, and does not need to, appeal to historicism in setting out his internal defence of political liberalism nor does anyone else in so using WRE need to make such a justification. But historicism, if we are to make an external justification of political liberalism, is useful and perhaps indispensable.

4. I neither argue for 4 nor think that what 4 claims is right. It is not right for, as has been noted, Nietzsche is a counter-example as are the philosophers that Isaiah Berlin calls philosophers of the counter-enlightenment. Georg Hamann (of whom Kierkegaard was a student) was the most pre-eminent among them. To be consistent, none of them need radically reverse their orientation and become political liberals.

5. This point is exactly on the mark. One can be an anti-foundationalist and a consistent and plausible one (e.g., Nietzsche or Burke) and still not be a political liberal and one could make a reasonable case for political liberalism, as Mill and Kant did in their time and C. I. Lewis did in ours, while remaining a foundationalist. What I do think is the case is that now the most plausible forms of political liberalism are anti-foundationalist or at least non-foundationalist. But this has more to do with how philosophy has turned than with political liberalism. (Moreover, it may very well be, indeed I think so, a good turn.) Moreover, this is not in conflict with any anti- hhilisophy philosophy.

6. This is true and importantly so and it accurately characterizes Rawls. And it is not a view that I deny or in any way contest, or is incompatible with anything I argue.

7. Again, this is true, though it is less important, and is something I have never denied nor would wish or need to deny for what I am claiming.

8. Perhaps we do not need to respond to an illiberal by invoking anti-foundationalism, particularly if we, like Rawls, are only giving an internal justification of political liberalism. But an illiberal can perhaps also give an internal justification of his illiberal views by using WRE. Faced with what maybe these competing internal justifications and being wary of appeals to foundations to either support one's own view or to critique the illiberal's, we could still be tempted to continue to appeal to WRE and examining the WRE appealed to by the political liberal and the one appealed to by the illiberal, we have reason to expect that most (if not all) illiberals would end up making empirical claims or putative empirical claims that are false or ones that claim such an empirical status but fail to gain it and thus are incoherent. For example, for the first alternative 'Any 
person can gain a good reasonably paying job if he vigorously seeks one,' and for the second alternative 'Some people are inherently inferior.'

9. This point asks whether by tying my defence of political liberalism to anti-foundationalism, I put, by that very procedure, in question whether one can consistently and plausibly be a political liberal if one believes in foundations? Clearly one can consistently so believe and, before there was any such tying, as with the near hegemony of anti-foundationalism, one should have said (and correctly) that Mill and Kant made plausible cases for political liberalism that could, before the extensive and powerful turn against foundationalism, be regarded not unreasonably to be very plausible. Moreover, there are some intelligent and well informed people now who still think that Mill or Kant's case is plausible - some think very plausible. ${ }^{58}$ But given the force of the pragmatist's work, Wittgenstein's, Quine's, Sellars's, Davidson's, Putnam's, Rorty's, Habermas's, and Brandon's holism, and anti-foundationalism, and, with some of the above, their historicism, they seem at least to have captured the day. I believe the 'seems' is too weak. It has captured the day and is not just a trend that will be reversed. Given that, it is not going to be the case for us now that a foundationalist political liberalism or any kind of foundationalism is going to be plausible. Of course, such historical prediction or conjectures can be mistaken, as they have been in the past. But for anyone who has studied analytic philosophy carefully the case will seem overwhelming. ${ }^{59}$ But, as in everything, we must be fallibilist about this. Moreover, it is not a self - contradiction or any kind of contradiction to be fallibilist about fallibilism. In fact, we must be if fallibilism is to go all the way down.

58 See, for a powerful example, Rawls's own treatment of Mill ("Lectures on Mill" in Samuel Freeman, ed., Lectures on the History of Political Philosophy (Cambridge, MA: Harvard University Press, 2007) at 251; and John Rawls, "Kant" in Barbara Herman, ed., Lectures on the History of Moral Philosophy (Cambridge, MA: Harvard University Press, 2000) at 141.

59 There still are impressive things in Mill and Kant's writings concerning what we now call political liberalism. Indeed, they are the classical texts concerning such matters. Perhaps what is so crucial about them here can be stated without making foundationalist assumptions. 